\title{
THE QUALITIES OF THE PUNISHMENT
}

\section{Gh. Diaconu}

\section{Gheorghe Diaconu}

Faculty of Juridical and Administrative Sciences, the Law Department

University of Pitești, Pitești, Romania Romania.

*Correspondence: Gheorghe Diaconu, Curtea de Apel Piteşti, 22 Victoriei St., Piteşti,

E-mail: gheorghe.diaconu@just.ro

\begin{abstract}
The punishment-measure of compulsion and mean of re-education for the convict - it has to meet certain qualities in order to achieve its goals in an actual and efficient way. Thus, the punishment has to be right, it has to be adaptable, inflictive and moralizing, it mustn't offend the good manners, it has to be equal for all persons and it has to be remissible and repairable.
\end{abstract}

Keywords: quality; right; adaptable; enforceable; remissible.

\section{Introduction}

The punishment's finality - the constraint, the reeducation and the prevention - it can be realised only if the punishment fulfills certain qualities; these qualities refer to the abstract punishment as it's provided within the law and they don't refer to the concrete punishment which is inflicted by the judge.

Consequently, the qualities which the punishment has to contain are as it follows: it has to be right; it has to be adaptable; it has to be inflictive and moralizing; it mustn't offend the good manners; it has to be equal for everyone; it has to be remissible and repairable.

The punishment has to meet certain qualities in order to achieve its goals in an actual and efficient way ${ }^{1}$. These qualities are estimated by considering the abstract punishment as it is provided by law and not by considering the concrete punishment that the judge enforces, because in the last case, the efficiency of the punishment depends on the mode in which the judge enforces the legal punishment to the concrete situation and it does not depend on the punishment's qualities that are stipulated by law.

In order to realise its goal, the punishment: has to be right, adaptable, inflictive and moralizing; it mustn't offend the good manners; it has to be equal for all; it has to be remissible and repairable.

There are also other requirements which are usually added to those mentioned above as those that refer to the necessity that the punishment has to be certain; it has to be public and others. But, these conditions refer to the punishment's mode of enforcement and they do not refer to the punishment in itself, thus they are not submitted to the present analysis.

\section{A. The punishment has to be right}

1. One of the principal requirements of the punishment refers to the fact that it has to be right, that is to say the punishment has to correspond to the gravity of the committed

\footnotetext{
${ }^{1}$ V. Dongoroz, Drept penal (Tratat), Institutul de Arte Grafice Publishing House, Bucharest, 1939, p. 586.
} 
offence. "The justice, especially consists in the fact that the punishment has to be equal to the offence", as Bodin said.

In the common language it is said that a punishment is unjust when the judges have punished an innocent person or when they have been too severe or too clement with the guilty person. But, the requirement we talk about, it takes into consideration the mode in which the legislator has provided it in the penal law and also the fact whether the punishment corresponds to the idea of justice ${ }^{2}$. The idea of justice has permanently evolved and is far from having an unaltered content. Thus, it was said with good reason that the entire history of the penal law is nothing else but the history of the punishment which has followed step by step the evolution of the idea of justice. In the old law and in the classical doctrine, it was promoted the idea that a punishment is right when it's proportionate to the committed offence and consequently when it's proportionate with the author's guilt. This fact would mean the identification of the requirement that the punishment has to be right with the condition of proportionality. Actually, the justice is not only a simple requirement of the punishment, but it is the resultant of all qualities that a punishment has to contain.

2. In the modern conception, a punishment is right, first of all, when it is necessary, that is to say when the legislator is obliged to resort to it. The legislator does not incriminate by chance, but it incriminates only those deeds which reach a certain degree of social danger that justifies the intervention of the penal law and the infliction of a punishment. Consequently, the legislator's will expressed in the legal frame of the incrimination norm justifies by the social dangerous character of the incriminated deed; if the concrete deed didn't present the level of social danger that justifies the enforcement of a sanction, the punishment provided by the legislator it wouldn't be necessary and it would be considered unjust.

In the Romanian penal legislation, the matter of the disproportion between the generic social danger and the concrete social danger it found its solution within the legal provisions of article $18^{1}$ combined with article 91 of the Penal Code. Thus, if the concrete deed doesn't present the social danger of an offence, it doesn't represent an offence and as a consequence it is not sanctionned with a punishment. In other legislations, the lack of concrete social danger of the deed it led to various regulations. Thus, the American Penal Code and the French new Penal Code contain provisions according to which in such cases, a punishment is not inflicted ${ }^{3}$ (therefore, the lack of social danger is a cause of non-punishing and it's not a cause of inexistence of the offence).

This means that when the legislator copes with an illicit fact and it has to react against it, it firstly has to examine if an extrapenal sanction isn't enough and only in the case when the intervention of the penal sanction (any other sanction is inefficient) is necessary, the punishment provided by law would be just.

The unjustness of the punishment represents the negation of law; a law which distinguishes by the unjustness of its sanctions, not only it cannot serve for the public interest, but also it would be the strongest source of attacks against the respective order ${ }^{4}$.

\footnotetext{
${ }^{2}$ Tonissen, Histoire du droit criminel, p. I, Bruxelles, 1869, p. 11.

${ }^{3}$ The American Penal Code (article 2.12) provides that "the court can give up the trial if considers that taking into consideration the imputed conduct and the circumstances of the case, then the doer's manifestation is placed within the limits of tolerance which are traditionally admitted and it doesn't infringe the goal pursued by the legislator"; the French new Penal Code (articles 132-58, 132-59) states the court's possibility to "dispense the defendant from any punishment if it results that his reeducation has been achieved"; in the same way, the German Penal Code $(\$ 60)$ provides the possibility that "the court has to give up the infliction of the punishment which doesn't exceed one year of prison when the consequences of the committed deed affected the defendant in such a large extent so that the pronouncement of a sentence would seem as useless".

${ }^{4}$ V. Dongoroz, Tratat, op. cit., p. 586.
} 
3. The punishment mustn't be either too severe or too clement, but it has to represent the equivalent of the social danger of the committed offence. The study of the punishment's history points out many cases of omission of the requirements regarding the justness and the proportionality. Thus, for instance, the Egyptian law in the days of Pharaoh Menes (approximately 5000 years before Christ) stated the death penalty for any offence ${ }^{5}$; Manu the ancient legislator in India, similarly established merciless punishments provided in Manava - Dharma - Sastra; "the Indian penal law is severe and the punishments are cruel enough", said Eschbach ${ }^{6}$. In the Hammurabi's ancient legislation, the punishments were too very severe and the death penalty was inflicted for the majority of the offences. Concerning the Greek people, the Dracon's laws are famous for their severity, as the same punishment (the death) was inflicted both to serious offences and to slight offences ${ }^{7}$. In Rome, according to the Law of the XII tables, pater familias had the power over life and death and the debtor who was bad payer could be sold and killed by his creditors; Emperor Nero made lamps from the convicts' bodies and he smeared them with black oil; the guilty slaves were given as food to "murene". In the Middle Age and even in the modern time, the punishments continued to be very severe. In France, many of the committed offences were punished by the death penalty ${ }^{8}$.

In the Romanian Countries, the severity of the punishments was as great as in the Occident. There are known the draconic punishments inflicted during the $\mathrm{XV}^{\text {th }}$ century; Vlad the Impaler, the voivode of Wallachia punished with the death penalty even the slightest offences. In the Pravila of Matei Basarab and Vasile Lupu, there can be found too some punishments very severe .

After thousands of years of barbarian severity, in the new times the punishments gradually became ridiculous because of their indulgence, thus the society wasn't defended anymore against the evil-doers. In part, this change was explained by the influence of the ideas that belonged to Cesare Beccaria who fought against the cruelty excess and he sustained that the punishment should become more human. Some of the legislators have understood that this fact justifies the passing into the other extreme, which means that the provided punishments were much disproportionated in comparison with the abstract social danger of the committed offence. The punishment's indulgence is not less dangerous; an insufficient punishment is as harmful as the excess of rigour; it results no good from such a punishment neither for the members of the society that are in danger, nor for the defendants that won't become better persons ${ }^{10}$.

Therefore, in order to get a right punishment, it's necessary that the legislator avoid the extreme points which are equally dangerous: neither excessive severity nor excessive indulgence. The modern legislations have to find a wise way in order to keep a fair balance between severity and tolerance, as it well said Carrara.

\section{B. The punishment has to be adaptable}

In order that the punishment should be well proportionated, the legislator has to choose those punishments which are adaptable to various levels of social danger of the deed and of the doer, from both quantitative and qualitative points of view.

\footnotetext{
${ }^{5}$ Diodor de Sicilia, Biblioteca Istorica, Book I; Platon, Legile, Book II, du Boys, Histoire du droit criminel des peuples anciens, Joubert Publishing House, Paris, 1845, p. 19.

${ }^{6}$ A. Eschbach, Introduction generale a l'etude du droit, 3-eme edition, Cotillon Publishing House, Paris, 1856, p. 608; Tonnisen, Histoire du droit criminel, p. I, p. 11.

${ }^{7}$ Plutarh, Viața lui Solon, XVII.

${ }^{8}$ Jousse, Justice Criminelle, I.II, p. 267.

${ }^{9}$ In gloss 259 , number 13 , it is stated that "any slave or naemit or servant that abducts a woman, then he not only suffers the death penalty, but also he is thrown in the fire".

${ }^{10}$ Bentham, Traite de lois, I.II, p. 144 and Theories des peines, p. 25.
} 
A punishment which is not susceptible of a qualitative differentiation that would allow a good proportioning and a perfect adequation of the sanction in its infliction, then it's a deficient and criticizable punishment because it has no elasticity. Such a punishment which isn't properly individualized by law, it makes impossible a proper judicial individualization.

Concerning the requirement of elasticity, the Romanian present Penal Code is criticizable because it establishes a restricted legal frame of principal punishments (actually, there are only two principal punishments because in fact the life imprisonment is a prison punishment which doesn't serve to the operation of individualization the penal repression. The narrowness of the system of sanctions isn't diminished not even in the cases of some substitutives of the punishments as the conditional suspension with its two forms or the execution of penalty at the working place which serve to the individualization of the prison sentence's execution.

From the quantitative point of view, the punishment has to be divisible in order to fulfill the requirements of proportionality and individualization.

In the juridical literature it has been stated with good reason that the adaptation of the punishments is made by the legislator in the very moment of drawing up the penal law by establishing the type and the limits of the punishment and also the extent in which they can be modified under the influence of the aggravating or of the attenuation causes ${ }^{11}$.

An adaptable punishment is that punishment which can be proportioned depending on the concrete social danger of the offence and of the offender and also depending on the aggravating or on the attenuation circumstances that were present when the offence was committed (according to the principle of individualization of the punishment). On this reason, the legal punishment is relatively fixed, except for some cases; it has a minimum and a maximum limit, not only general, but also a special one. There are also provided alternative punishments for the same offence, each of them with its own special limits, in order that the punishment should be as corresponding as possible to the offence's concrete danger.

Regarding this aspect, the death penalty which is still provided in certain legislations, it's unadaptable from both elasticity and divisibility points of view; in contrast with the life imprisonment which is elastic because it can be adapted from the qualitative point of view, even if it is indivisible.

\section{The punishment has to be inflictive and moralizing}

1. The punishment is inflictive and moralizing when it represents a suffering for the convict. The punishment itself defines as an evil, as a suffering which is imposed to the convict against his will ${ }^{12}$. When it is said that a punishment has to be inflictive it means that it has to be able to create a feeling of constraint, of shame, of discontent from which it has to derive the feeling of suffering or at least, the feeling of pleasure has to be absent. The punishment has to generate this effect in all its moments: when is written in the incrimination norm, when it's inflicted and when the punishment is executed. The punishment that doesn't cause such feeling it won't have force of inhibition and the observance of law will be implicitly compromised. Also, a punishment regarded as inflictive, in abstracto, but by its mode of execution would remove any feeling of displeasure and it would be perfectly agreeable, then it would lose any intimidating force.

In the modern vision concerning the punishment, from the multitude of punishments, the legislator mustn't choose the one that is the most inflictive because this fact would mean

\footnotetext{
${ }^{11}$ V. Dongoroz, Explicații teoretice ale Codului penal român, partea generală, second volume, Academy Publishing House, Bucharest, 1970, p. 119; V. Dongoroz, Tratat, op. cit., p. 651; I. Oancea, Drept penal. Partea generală, Didactica and Pedagogica Publishing House, Bucharest, 1971, p. 421; M. Basarab, Drept penal. Partea generală, Lumina Lex Publishing House, Bucharest, 1997, p. 226.

${ }^{12}$ G. Antoniu, Contribuții la studiul esenței, scopului şi funcțiilor pedepsei, Revista de drept penal number 2/1998, p. 10.
} 
to turn back to the barbarous punishments. But, the legislator is obliged not to adopt the repressive measures which are the less inflictive. The legislator has to select the punishments which are able to satisfy the social group's moral conscience.

2. The punishment's inflictive character mustn't be confounded with the conviction's dishonouring character ${ }^{13}$. A conviction can be more or less inflictive in comparison with another conviction to a severer or to a less severe punishment. But, concerning other aspects, the modern conception over the punishment oposes to the punishment's dishonouring character. An offender can be convicted to a severe punishment, but he may not draw the public opprobrium upon him and vice-versa, an offender can be acquitted and the members of the society still refuse him any feeling of respect. Concerning the dishonour, the echo generated by the conviction in the public opinion it's enough because it's directly proportional to the punishment which is more or less inflictive. Any excess concerning this aspect, it perverts the person instead of reforming him. If the legislator doesn't have to establish punishments which would represent a pleasure for the convict by their treatment; it's also true that the legislator mustn't fall into the other extreme and he mustn't transform the punishment into an opportunity of torments which are far from moralize him but, on the contrary, they humiliate the convict, they discourage and enrage him.

In the old legislations, the punishments usually caused great sufferings but the punishments' cruelty, far from being an obstacle for the criminality, they have hardened the manners and they have developped the brutality ${ }^{14}$.

As the society cannot oblige the offender to expiation, she also cannot constrain him to moralization but at the same time, the punishment mustn't be demoralizing. A similar idea was stated by Bettiol who pointed that by the punishment is not pursued the convict's moralization against his will, but its goal is to form certain minimal manners in order that the offender should not commit offences in the future ${ }^{15}$.

The requirement that the punishment mustn't be demoralizing is acknowledged by all the modern legislations, including the Romanian one where it's provided that "the punishment's execution must not cause physical pains and it cannot humble the convict's person", according to the final part of article 52, paragraph 2. But, it's possible that a punishment regarded in abstracto, it may not be demoralizing when it's drawn up in the law but it may get this character when it's concretely inflicted.

\section{The punishment mustn't offend the good manners}

According to this requirement, the punishment has to be decently inflicted and it cannot be a mean of mockery for the offender. In the past times, there were utilized various forms of punishments that humbled the convict to the very depths of his soul and also they excited and they let go free the crowd's abject feeling. The convicts were often exposed in the public square, wearing mocking clothes and they were let in the public's power that spitted upon them and they threw stones at them. At other times, the convicts were carried in mocking postures on the streets and also, there is no need to mention the various torments that accompanied the execution, in everybody's sight and delight.

Ignominious punishments can be found in the old Romanian regulations; thus Pravila of Matei Basarab, Chapter 237, stipulated the mode in which the man married with 2 women or the woman married with 2 men were "scolded": "the one who has two women, you have to carry him naked on the lane, riding on a donkey and you must keep beating him with two

\footnotetext{
${ }^{13}$ R. Saleilles, L'individualisation de la peine, F. Alcan Publishing House, Paris, 1898, p. 225; E. Ferri, La sociologie criminelle, F. Alcan Publishing House, Paris, 1905, p. 448.

${ }^{14}$ V. Dongoroz, Tratat, op. cit., p. 187.

15 G. Bettiol, "Nuovo Difesa Sociale" considerata da un punto de vista catolico (considerated by the catholic point of view) in Scritti Giuridici, Padova, 1966, p. 1009.
} 
distaffs that the women utilize to spin; you have to do the same with the woman that take two men, you have to carry them naked, riding on a donkey and you must beat them with two comanace or with two islice" 16 .

Such punishments existed in the states of Western Europe. The history states the mode in which widow Desbleds was punished on 4 August 1791. She was exposed in the square Palais Royal in Paris, riding on a donkey, with her face turned towards the donkey's tail and wearing a straw hat with the inscription "corrupter of young people"17.

The drawback of these punishments was that they injuried not only the convict but also they injuried the society's members feelings of chastity. They were far from generating morality and they represented a permanent impulse to disorder.

Among the dishonourable punishments, a special place has been occupied, until nowadays, by the beating ${ }^{18}$, although such a character has been denied for $\mathrm{it}^{19}$. Thanks to the works that belong to the great humanist thinkers, especially to Beccaria, the modern penal law has gradually removed these features of the punishment and it has promoted the principle according to which the punishments have to correspond to the good manners.

Respecting the human dignity became one of the points of support of the penal intervention; the punishment, in order to achieve its goal, it mustn't lead to the loss of honour, but it has to contribute to its retrieval, thus the dignity can take its place inside the conscience. The offender is deprived of liberty and not of dignity ${ }^{20}$. The protection of human dignity represents an imperative aspect which regards the whole criminal trial or the penitenciary; this fact doesn't mean that the offenders shouldn't be punished because of respecting the human dignity, but it obliges to a proper framing within norms and structures that can ensure this major desideratum, with the perspective that the dignity should hold a decisive place inside their own conscience.

\section{E. The punishment has to be equal for everyone}

1. This requirement gives expression to the principle of equality before the law; in other words, the same offence has to be punished within the same limits of punishment, without distinction among persons.

This principle was unknown to the old legislations, the judges could resort to arbitrary punishments, they punished in a certain mode when the offence was committed by persons that had a social position in the society and they punished in a different way when the deed was committed by ordinary people. In the ancient law of Manu, the inequity was so common that it represented a legislative principle ${ }^{21}$. The inequity before the law existed in the Romanian legislation too; for instance, "if the man killed the woman caught in the act, he was sentenced to life exile if he was an ordinary person and if he had a certain social condition; he was exiled for a limited period of time"22. Pravila of Matei Basarab abounded with such types of example: "neither the boyards, nor their sons are punished with the galley or with the salt work, but they are expelled from their landed property for a while; they are not hanged in

\footnotetext{
${ }^{16}$ Similar provisions can be found in the Pravila of Vasile Lupu, Chapter 15, Longinescu Publishing House, Legi vechi româneşti, Bucharest, 1912, p. 131.

${ }^{17}$ G. Mace, Gibier de Saint Lazare, second edition, G. Charpentier Publishing House, Paris, 1888, p. 305.

${ }^{18}$ In Romania the beating was abolished in 1864, in Austria in 1876, in Sweden in 1855, in Serbia in 1873.

19 Thus, I. Tanoviceanu stated that "what dishonours the person, it cannot be the punishment that is other person's fact, but the offence which is his own fact", Tratat de drept penal şi procedură penală, third volume, Curierul Judiciar Publishing House, Bucharest, 1924, p. 184.

${ }^{20}$ Theodore Papatheodoru, De l'individualisation des peines et la personalisation des sanctions, Revue Internationale de Criminologie et de police tehnique, number 1/1993, p. 109.

${ }^{21}$ As Manava- Dharma-Sastra said, "the king has to beware of killing a brahman even if he had committed all the possible murders" (Lois de Manon, VIII, 380); "For adultery, the brahman is submitted to the shameful haircutting while the individuals of other social classes are killed" (Tonnisen, op. cit., I, p. 62).

${ }^{22}$ Pravila of Vasile Lupu, chapter 64.
} 
pitchforks as other evil-doers, they are not pricked, they are not carried on the lane or in the square as other evil-doers are carried" 23 or "the Pravila changes the bodily punishment with the money sanction when it's about a boyard" (chapter 234).

The punishment's inequity existed in Romania until the modern period. As a proof, we mention the Condica criminaliceasca Ionita Sturdza in 1826 (paragraph 253), Condica criminaliceasca Bibescu in 1841 (articles 25 and 33) and Codicele penal of prince Stirbey in 1850 that established "The noble by his family, rank or profession as are the boyards, the traders, the doctors, the lawyers and other with a distinct character, they aren't submitted to beating, although the beating is provided amongst the punishments of this code, but when the judge inflicts it, he always has to take into consideration the character and the social position for any convicted person".

In the $\mathrm{XVI}^{\text {th }}$ century, Tiraqueau justified this solution "an easier punishment is given to the offenders owing to their birth's honour and to their ancestors' nobleness" ${ }^{24}$. The same inequity is mainteined in the XVIII ${ }^{\text {th }}$ century; in this respect, Montesquieu showed that "in case of murders, the noble loses his honour, while a physical punishment is inflicted to the ordinary person who hasn't honour" ${ }^{\prime 2}$. The spirit of inequity went so far in punishing the offenders and sometimes degenerated into ridiculous ${ }^{26}$.

The principle of equality of the punishments doesn't exclude the fact that the penal law may stipulate for a different way of sanctioning for the persons that had a certain quality when they committed the deed ${ }^{27}$ (for instance, public officer, military man and others) or for the offender who is a minor person.

Also, the observance of this principle doesn't exclude the fact that the punishment may have unequal effects, depending on each convict's sensibility.

No matter the perfection of the criteria of proportioning and adequation of the punishment, they couldn't equalize the convicts' suffering because each of the individuals will endure the punishment in a different way; they cannot equalize either the suffering for those who indirectly feel the punishment's effects (the convict's family) or the satisfaction for those injuried by the committed deed; they cannot equalize the punishment's echo in the public opinion or the final result of the punishment.

\section{$F$. The punishment has to be remissible and repairable}

1. The act of justice as any other human act is not infallible and often a complex of coincidences can cause an unjust conviction sentence. For this reason, it's necessary for the society to have the proper mean in order to repair the evil suffered by an innocent person ${ }^{28}$. As Pastoret said, "the punishment mustn't be of such type thus it couldn't be repaired if the crowd was wrong" ${ }^{29}$. Carrara, going further on with this idea, stated that "to convict an innocent person is a real social misfortune by the scare caused to the citizens" ${ }^{30}$.

Incontestably, an unjust sentence is a great evil but the evil is even greater if the mistake was recognized but the society wouldn't have the possibility to repair it. Therefore, the legislator always has to take into consideration the eventuality of such mistake and he must choose only those punishments that can be removed and repaired in case of error; in

\footnotetext{
${ }^{23}$ Pravila of Matei Basarab, chapter 367; similar dispositions can be found in the Pravila of Vasile Lupu, chapter 62.

${ }^{24}$ Tiraqueau, LI, number 45, p. 282.

${ }^{25}$ Montesquieu, Esprit de lois, Book VI, chapter X.

${ }^{26}$ Benjamin Disraeli Coningsby (Book IV, chapter IV), mentioned the case of lord Ferres in England. The lord was sentenced for murder in the time of George II. Despite all the lords' oppositions, he was finally hanged, but with a string of silk.

${ }^{27}$ V. Dongoroz, Tratat, op. cit., p. 672.

${ }^{28}$ V. Dongoroz, Tratat, op. cit., p. 588; I. Tanoviceanu, op. cit., third volume, p. 146.

${ }^{29}$ Pastoret, Lois penales, I.I, p. 22.

${ }^{30}$ Carrara, Programma..., paragraph 651.
} 
other words, in case of establishing that the convict was the victim of a miscarriage of justice (he was punished without being guilty) then it has to exist the possiblity to remove it (to remit it) and so the evil suffered by the convict can be repaired ${ }^{31}$. To repair a miscarriage of justice doesn't mean only to cease the conviction's effects, but also to annihilate as much as possible the suffering caused to the one who was unjustly sentenced.

In order that the punishments should be repairable, they have to be revokable and remissible by their nature and this means that they can be removed when their execution hasn't started or that the execution can be stopped if was started. The punishment is neither revokable nor remissible when its effects are definitive and it's impossible to repair them. Concerning this aspect, the death penalty and the punishments that are executed over the human body are mainly irreparable and irremissible. The death penalty is still inflicted in many states ${ }^{32}$, while the other punishments were removed at the beginning of the modern age $^{33}$.

2. The legislations of many countries including Romania contain reparative provisions in case of an unjust conviction. Thus, articles 504-507 of the Romanian Code of Penal Procedure as it was altered by Law number 32/1990 and by Law number 104/1992, it states a special proceeding by which the person who was the victim of a miscarriage of justice can request the state to repair the suffered prejudice ${ }^{34}$. According to this proceeding, both material and moral prejudices that were suffered by the person who was unjustly convicted can be repaired.

But this fact doesn't mean that any unjust punishment is totally repairable ${ }^{35}$. Thus, concerning the prison sentence, the privation of liberty and the suffering caused for a certain period of time, it cannot be repaired anymore. Not even the punishment to fine isn't entirely repairable and as Laborde said "the fine is returned but the benefits, the opportunities that were lost in speculations and enterprises are they ever returned?"

\section{Conclusions}

In front of an illicit fact, the legislator, firstly, has to examine if an extrapenal sanction isn't enough and only in the case when the intervention of the penal sanction (any other sanction is inefficient) is necessary, the punishment provided by law would be just.

The unjustness of the punishment, including the non-fulfillment of the necessary qualities, it only represents the negation of law; a law which distinguishes by the unjustness of its sanctions, not only it cannot serve for the public interest, but also it would be the strongest source of attacks against the rule of law.

The punishment must be neither too severe nor too tolerant, but it has to represent the equivalent of the social danger of the committed offence.

A punishment that doesn't fulfill the qualities mentioned above, it's as harmful as the excess of rigour; it results no good from it, neither for the members of the society that are endangered because of the offences, nor for the defendants that won't become better persons.

\footnotetext{
${ }^{31}$ V. Dongoroz, Tratat, op. cit., p. 588.

${ }^{32}$ In Romania, the death penalty was abolished by the Decree-law number 6 on 10 January 1990 and it was replaced with the life imprisonment.

${ }^{33}$ In the Romanian Countries, the corporal punishments were prohibited by the Organic Regulations of Muntenia and Moldavia which established that "The punishments by cutting the hands and also the torments or the works are destroyed and they are abolished and they cannot be inflicted from now on" (articles 298 and 385).

${ }^{34}$ N. Volonciu, Tratat de procedura penala, second volume, Bucharest, p. 236; I. Neagu, Tratat de procedura penală, Pro Publishing house, Bucharest, 1997, p. 723; in the French legislation it was inserted a double reparation: a moral reparation and a pecuniary one.

35 Bristol de Varville, Le sang de l'innocent renge, p. 56; Theorie des lais criminelles, Neuchatel Publishing House, Utrecht, 1791, p. 56.

${ }^{36}$ A. Laborde, Cours de droit criminel, Rousseau Publishing House, Paris, 1891, p. 79.
} 


\section{Bibliography}

Antoniu G., Contribuții la studiul esenței, scopului şi funcțiilor pedepsei, Revista de drept penal number 2/1998; 1997 ;

Basarab M., Drept penal. Partea generală, Lumina Lex Publishing House, Bucharest,

Neagu I., Tratat de procedura penală, Pro Publishing House, Bucharest, 1997;

Papatheodoru T., De l'individualisation des peines et la personalisation des sanctions, Revue Internationale de Criminologie et de police tehnique, number 1/1993;

Oancea I., Drept penal. Partea generală, Didactica and Pedagogica Publishing House, Bucharest, 1971;

Dongoroz V., Explicații teoretice ale Codului penal român, partea generală, second volume, Academy Publishing House, Bucharest, 1970;

Bettiol G., "Nuovo Difesa Sociale" considerata da un punto de vista catolico (considerated by the catholic point of view) in Scritti Giuridici, Padova, 1966;

Dongoroz V., Drept penal (Tratat), Institutul de Arte Grafice Publishing House, Bucharest, 1939;

Tanoviceanu I., Tratat de drept penal şi procedura penală, third volume, Curierul Judiciar Publishing House, Bucharest, 1924;

Legi vechi româneşti, Longinescu Publishing House, Bucharest, 1912;

Ferri E., La sociologie criminelle, F. Alcan Publishing House, Paris, 1905;

Saleilles R., L'individualisation de la peine, F. Alcan Publishing House, Paris, 1898;

Laborde A., Cours de droit criminel, Rousseau Publishing House, Paris, 1891;

Mace G., Gibier de Saint Lazare, second edition, G. Charpentier Publishing House, Paris, 1888;

Eschbach A., Introduction generale a l'etude $d u$ droit, third edition, Cotillon Publishing House, Paris, 1856;

Du Boys A., Histoire du droit criminel des peuples anciens, Joubert Publishing House, Paris, 1845;

Bristol de Varville, Theorie des lais criminelles, Neuchatel Publishing House, Utrecht, 1791. 